\title{
KARAKTERISTIK ADSORBEN KARBON AKTIF DARI LIMBAH PADAT KELAPA SAWIT (REVIEW)
}

\author{
CHARACTERISTICS OF ACTIVATED CARBON ADSORBENT \\ FROM OIL PALM SOLID WASTE (REVIEW)
}

\author{
Dwi Ermawati Rahayu ${ }^{12)}$, Wahyono Hadi' ${ }^{2}$ \\ 1) Program Studi Teknik Lingkungan Universitas Mulawarman Samarinda \\ 2) Jurusan Teknik Lingkungan Institut Teknologi Sepuluh November Surabaya
}

\begin{abstract}
Abstrak
Agroindustri kelapa sawit menghasilkan limbah biomassa dengan volume yang besar. Limbah tersebut berpotensi untuk dimanfaatkan menjadi bioadsorben untuk digunakan dalam pengolahan air limbah, air minum dan remediasi tanah. Kualitas adsorben yang baik mempunyai karakteristik porositas tinggi, stabilitas fisik kimia dan luas area permukaan besar. Untuk menghasilkan bioadsorben karbon aktif maka dilakukan proses karbonisasi dilanjutkan dengan proses aktivasi. Proses ini meliputi aktivasi fisik, kimia serta gabungan fisikkimia maupun kimia-fisik. Aktivasi bertujuan untuk meningkatkan mesopori dan makropori sehingga dihasilkan karbon aktif dengan luas permukaan spesifik yang besar. Pemilihan proses aktivasi secara fisik, kimia asam atau basa untuk proses aktivasi akan berpengaruh terhadap karakteristik karbon aktif yang dihasilkan,terutama berpengaruh terhadap afinitas alifatik grup fungsional yang terdapat pada permukaan atas karbon aktif.
\end{abstract}

Kata kunci: adsorben, karbon aktif, limbah padat kelapa sawit

\section{Abstract}

Palm agricultural lignocellulosic biomas generate the abundant amount of biomass waste. The biomass wastes had potential to be utilized as a bioadsorbent for water and wastewater treatment, soil remediation. Great quality of adsorbent has characteristic of high porosity, pshycochemical stability, large specific surface area. Bioadsorben activated carbon processed with carbonization in the first step and then followed by activation process. The process consist of physical, chemical and physical-chemical activation. The activation purpose is to increase mesoporocity and macrporosity so that activated carbon with large specific surface area are produced. The effect of different activation process and the characteristic of activated carbon products were reviewed.

Keywords: activated carbon, adsorbent, oil palm solid waste

\section{PENDAHULUAN}

Agroindustri kelapa sawit berkembang pesat di kawasan Asia Tenggara terutama Indonesia dan Malaysia disebabkan meningkatnya konsumsi minyak dunia. (Hansen, 2015). Kegiatan di sector ini akan menghasilkan limbah biomassa dengan volume yang cukup besar berupa tempurung biji sawit 5,5-7\%, tandan kosong 22$23 \%$, pelepah sawit 13,5-15\% (Kong, 2014). Limbah biomassa umumnya dimanfaatkan sebagai bahan bakar boiler pada industri minyak Sawit (Kong, 2014). Selain sebagai bahan bakar, limbah biomassa mempunyai potensi besar untuk dikonversi sebagai bioadsorben yang berkualitas. Bioadsorben tersebut dapat digunakan dalam pengolahan air minum (Mohan, 2014, Summers, 2013 (Gupta, 2009; Sharma, 2011; Crini, 2006; Mittal, 2013) pengolahan air limbah Sadeek, 2015; Ujile, 2013; Khosravihaftkhany, 2013; Mohan, 2006; Wan, 2010; Bilal, 2013; Ghasemi (2014), remediasi tanah (Kong, 2014). Kualitas 
bioadsorben yang baik mempunyai karakteristik fisik dan kimia yaitu porositas yang tinggi, stabilitas fisik kimia, luas area permukaan besar (Yahya, 2015; Oramahi, 2015, Fuadi, 2014; Hesas, 2013; Bilal, 2013; Joseph, 2009). Untuk menghasilkan bioadsorben karbon aktif maka dilakukan proses karbonisasi dilanjutkan dengan proses aktivasi. Proses ini meliputi aktivasi fisik, kimia serta gabungan fisik-kimia maupun kimia-fisik (Hesas, 2015; Widyastuti, A., 2013) dengan berbagai jenis aktivator. Proses aktivasi akan berpengaruh pada sifat sifat dari karbon aktif yang tidak terbentuk secara alamiah. Namun dipengaruhi oleh affinitas alifatik fungsional grup yang terdapat pada permukaan atas karbon aktif (Das, 2015). Aktivasi akan menghilangkan bagian karbon yang tidak terbentuk pada proses pengarangan sehingga bagian permukaan menjadi terbuka membentuk struktur mikropori. Struktur pori dapat diperbesar dengan menghilangkan dinding antar pori sehingga meningkatkan mesopori dan makropori. Produk akhir proses ini akan menghasilkan karbon aktif dengan luas permukaan spesifik yang besar (Nowicki, 2015). Sehingga pemilihan proses aktivasi secara fisik, kimia asam atau basa untuk proses aktivasi akan berpengaruh terhadap karakteristik karbon aktif yang dihasilkan. Kajian ini diperlukan untuk mengetahui pengaruh dari aktivasi asam basa terhadap karakteristik adsorben yang dihasilkan sehingga dihasilkan karakteristik karbon aktif yang sesuai dengan parameter air limbah maupun air bersih yang akan diturunkan.

\section{Limbah Padat Kelapa Sawit Pada Proses Produksi Palm Knell Oil}

Pelepah kelapa sawit merupakan limbah padat yang dihasilkan dari proses peremajaan pohon kelapa sawit. Satu hektar tanaman kelapa sawit menghasilkan pelepah daun sebanyak 10,4 ton dari pangkasan per tahun (Departemen pertanian, 2006). Satu hektar tenaman sawit akan dihasilkan 6.400 - 7.500 pelepah pertahun. Pelepah ini mengandung selulosa $(16,6 \%)$, hemiselulosa $(27,6 \%)$ dan silika $(3,8 \%)$. Tanaman kelapa sawit yang tumbuh memiliki pelepah berjumlah 40 - 60 buah dengan panjang mencapai 7,5 - 9 meter, Jumlah anak daun pada tiap pelepah antara 250 - 400 helai.

Limbah padat agroindustri kelapa sawit tersebut berasal dari kegiatan di perkebunan kelapa sawit itu sendiri dan di industry pengolahan sawit, sebagaimana diagram alir sesuai gambar 1 . Limbah padat yang dihasilkan dari agroindustri kelapa sawit adalah pelepah, pohon sawit dari perkebunan di sektor hulu. Sedangkan tandan buah kosong, serat buah, cangkang biji dari industri pengolahan kelapa sawitnya.

\section{Karakteristik Limbah Padat Biomassa}

Limbah padat kelapa sawit tergolong material lignoselulosik yang disebut juga photomass karena dihasilkan dari proses fotosintesis (Abdolali, 2014). Terdapat beberapa tipe sellulosa yang terdapat di dinding sel material lignoselulose. Material tersebut meliputi tiga komponen yaitu sellulosa, hemiselulosa dan lignin . Sekitar $65 \%$ sellulosa merupakan komponen yang dapat berbentuk kristal yang tidak larut dalam air. Struktur sellulosa berikatan dengan hemisellulosa (20-40\%) dan lignin (1525\%) (Abdolali, 2014). Sellulosa tidak terlarut dalam air pada suhu ruang namun sebagian akan terlarut pada suhu $302^{\circ} \mathrm{C}$ dan terlarut seluruhnya pada suhu $330^{\circ} \mathrm{C}$ (Kumar, 2008).

Hemisellulosa merupakan komponen yang kompleks dengan banyak cabang dan heterogennya jaringan polimernya, didasarkan pada pentosa termasuk xylose dan arabinose berbentuk glukosa, mannosa, galaktosa dan asam gula (Guidicianni, 2013). Bentuk hemisellulosa sekitar 20-30\% dari berat kering tanaman kayu. Bentuk hemisellulosa lebih tidak stabil sehingga lebih mudah untuk didegradasi oleh panas. Lignin merupakan heteropolymer yang terdiri dari tiga komponen yaitu hydroxycinnamyl alcohol monomers yang berbeda beda dalam tingkatan methoxylation p-coumaryl, coniferyl dan sinapyl alkohol (Giudicianni, 2013). Lignin terdapat pada $18-25 \%$ kayu keras dan 25-35\% pada kayu lunak. Tanaman menggunakan lignin sebagai penguat struktur, menahan aliran fluida, mencegah serangan mikroorganisme dan menyimpan energi. 
Penelitian terhadap limbah biomassa yang mempunyai komposisi dominan lignin, agroindustry kelapa sawit menunjukkan sedangkan tipe limbah padat yag lain memiliki karakteristik kandungan sellulosa, rasio komponen yang tertinggi adalah hemisellulosa dan lignin dari masing masing sellulosanya. Hal ini akan berpengaruh terhadap bagian seperti tabel 1. Hanya cangkang sawit karakteristik adsorben yang dihasilkan.

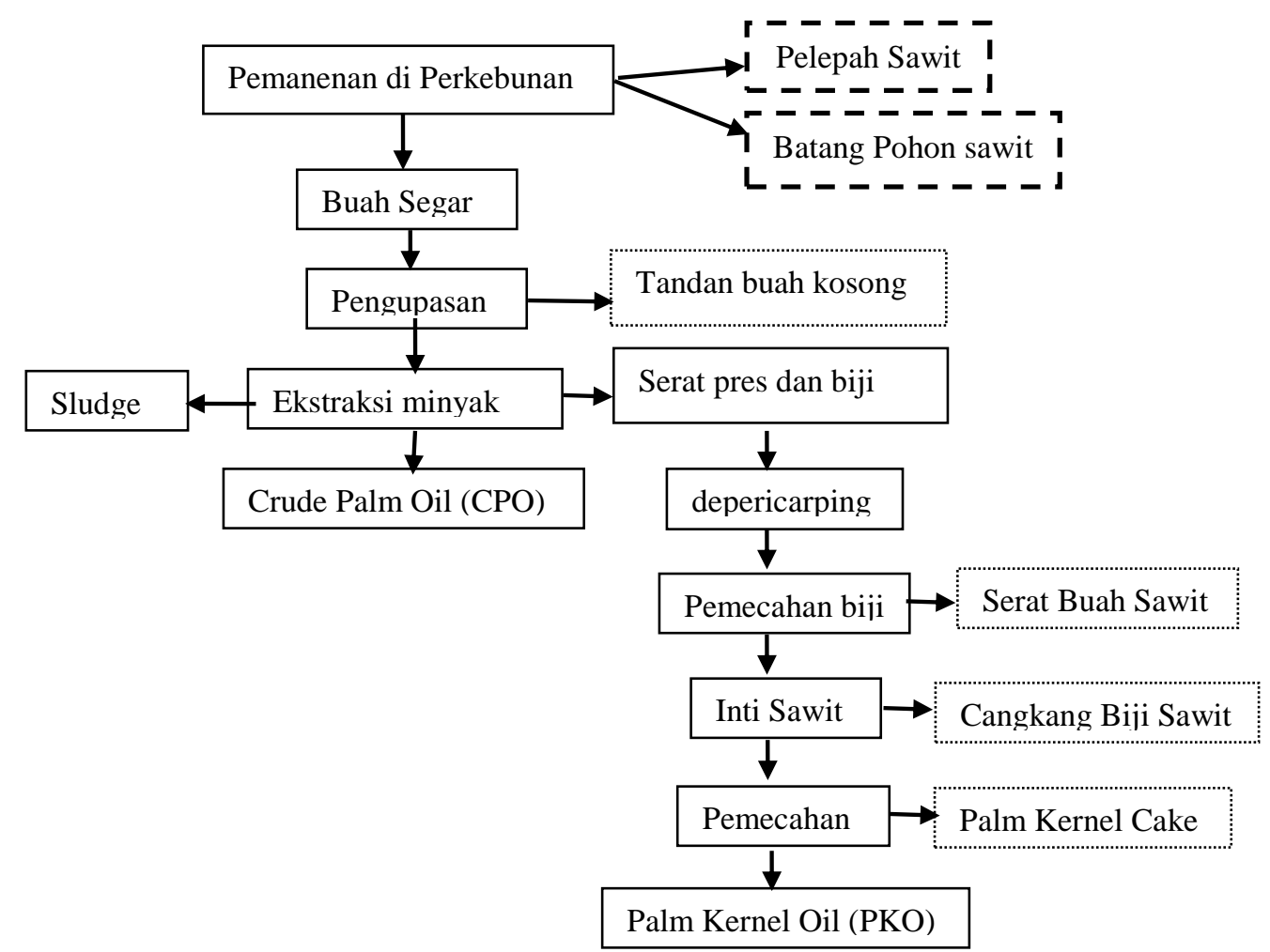

Keterangan :

- L : Limbah Padat yang dihasilkan

Gambar 1. Diagram Alir Proses Produksi Agroindustri Kelapa Sawit

Sumber (Abdolali, 2014, Saswattecha, 2015)

Tabel 1. Karakteristik kandungan biomassa

\begin{tabular}{lcrr}
\hline \multirow{2}{*}{$\begin{array}{c}\text { Tipe } \\
\text { biomassa }\end{array}$} & \multicolumn{3}{c}{ Komponen kimia (\% berat kering) } \\
\cline { 2 - 4 } & $\begin{array}{l}\text { hemisell } \\
\text { ulosa }\end{array}$ & Sellulosa & Lignin \\
\hline $\begin{array}{l}\text { Serat } \\
\text { mesocarp }\end{array}$ & 26,1 & 33,9 & 27,7 \\
\hline $\begin{array}{l}\text { Tandan buah } \\
\text { kosong }\end{array}$ & 35,3 & 38,3 & 22,1 \\
\hline $\begin{array}{l}\text { Cangkang } \\
\text { buah sawit }\end{array}$ & 22,7 & 20,8 & 50,7 \\
\hline $\begin{array}{l}\text { Batang pohon } \\
\text { sawit }\end{array}$ & 23,94 & 34,44 & 35,89 \\
\hline Pelepah sawit & 23,18 & 50,33 & 21,7 \\
\hline $\begin{array}{l}\text { Daun kelapa } \\
\text { sawit }\end{array}$ & 22,97 & 32,49 & 26,00 \\
\hline $\begin{array}{l}\text { Tulang daun } \\
\text { kelapa sawit }\end{array}$ & 23,17 & 46,1 & 29,31 \\
\hline
\end{tabular}

Sumber: (Kong, 2014; Abnisa, 2015)

\section{Karbon Aktif}

Secara konvensional karbon aktif merupakan sintesis char dari proses pirolisis material organik yang diaktivasi secara fisik maupun kimia pada temperatur tinggi (Islam, 2015).

\section{Pembuatan Karbon Aktif}

Karbon aktif dapat dibuat dengan beberapa metode pemanasan yaitu pirolisis dengan berbagai tipe dan produk yang dihasilkan sebagaimana tabel berikut ini: 
Tabel 2. Tipe Pirolisis, Kondisi Operasional dan Produk yang Dihasilkan

\begin{tabular}{|c|c|c|}
\hline $\begin{array}{l}\text { Tipe } \\
\text { pirolisis }\end{array}$ & $\begin{array}{l}\text { Kondisi } \\
\text { Operasional }\end{array}$ & $\begin{array}{l}\text { Produk } \\
\text { yang } \\
\text { dihasilkan }\end{array}$ \\
\hline Cepat & $\begin{array}{l}\text { Suhu reaktor } 500 \\
{ }^{\circ} \mathrm{C} \\
\text { Kecepatan } \\
\text { pemanasan sangat } \\
\text { tinggi }>1000 \\
{ }^{\circ} \mathrm{C} / \text { det } \\
\text { Waktu tinggal uap } \\
\text { sekitar } 1 \text { detik }\end{array}$ & $\begin{array}{l}\text { Padatan } \\
12 \% \\
\text { Cairan } \\
75 \% \\
\text { Gas } 13 \%\end{array}$ \\
\hline Sedang & $\begin{array}{l}\text { Suhu reaktor } 400- \\
500{ }^{\circ} \mathrm{C} \\
\text { Kecepatan } \\
\text { pemanasan 1-1000 } \\
{ }^{\circ} \mathrm{C} / \text { detik } \\
\text { Waktu tinggal uap } \\
\text { sekitar } 10-30 \text { detik }\end{array}$ & $\begin{array}{l}\text { Padatan } \\
25 \% \\
\text { Cairan } \\
50 \% \\
\text { Gas } 25 \%\end{array}$ \\
\hline Lambat & $\begin{array}{l}\text { Suhu reaktor } 290^{\circ} \mathrm{C} \\
\text { Kecepatan } \\
\text { pemanasan } \\
1^{\circ} \mathrm{C} / \text { detik } \\
\text { Waktu tinggal uap } \\
\text { sekitar } 30 \text { menit }\end{array}$ & $\begin{array}{l}\text { Padatan } \\
77 \% \\
\text { Cairan 0- } \\
5 \% \\
\text { Gas } 23 \%\end{array}$ \\
\hline Lambat & $\begin{array}{l}\text { Suhu reaktor } 400- \\
500^{\circ} \mathrm{C} \\
\text { Kecepatan } \\
\text { pemanasan sangat } \\
\text { tinggi } 1^{\circ} \mathrm{C} / \text { detik } \\
\text { Waktu tinggal uap } \\
\text { sekitar } 1 \text { detik }\end{array}$ & $\begin{array}{l}\text { Padatan } \\
33 \% \\
\text { Cairan } \\
30 \% \\
\text { Gas } 35 \%\end{array}$ \\
\hline
\end{tabular}

Sumber: Kong, 2014

Pada proses pirolisis, bahan baku yang mengandung komponen sellulosa, hemiselulosa dan lignin maka akan mengalami perubahan menjadi komponen sebagaimana tabel 3 .

Tabel 3. Hasil Pirolisis Komponen Sellulosa, Hemiselulosa dan Lignin

\begin{tabular}{lrrr}
\hline \multirow{2}{*}{ Sampel } & \multicolumn{3}{c}{ Prosentase (\% berat) } \\
\cline { 2 - 4 } & Bio oil & Gas & Char \\
\hline Sellulosa & 81,41 & 12,15 & 6,44 \\
\hline Hemiselulosa & 44,20 & 36,73 & 19,05 \\
\hline Lignin & 21,77 & 37,90 & 40,33 \\
\hline
\end{tabular}

Sumber : Wang, 2011
Berdasarkan tabel tersebut maka dekomposisi komponen bahan baku akan sangat berpengaruh terhadap produk hasil pirolisis. Untuk memperoleh GAC dan biochar maka komponen utama yang arus terdapat dalam bahan baku dalam jumlah yang besar adalah komponen lignin yang 40,33\%.nya akan terdekomposisi menjadi arang. Selain dengan pirolisis, pembuatan karbon aktif dan biochar dapat dilakukan dengan dengan metode hidrotermal sebagaimana gambar berikut ini:

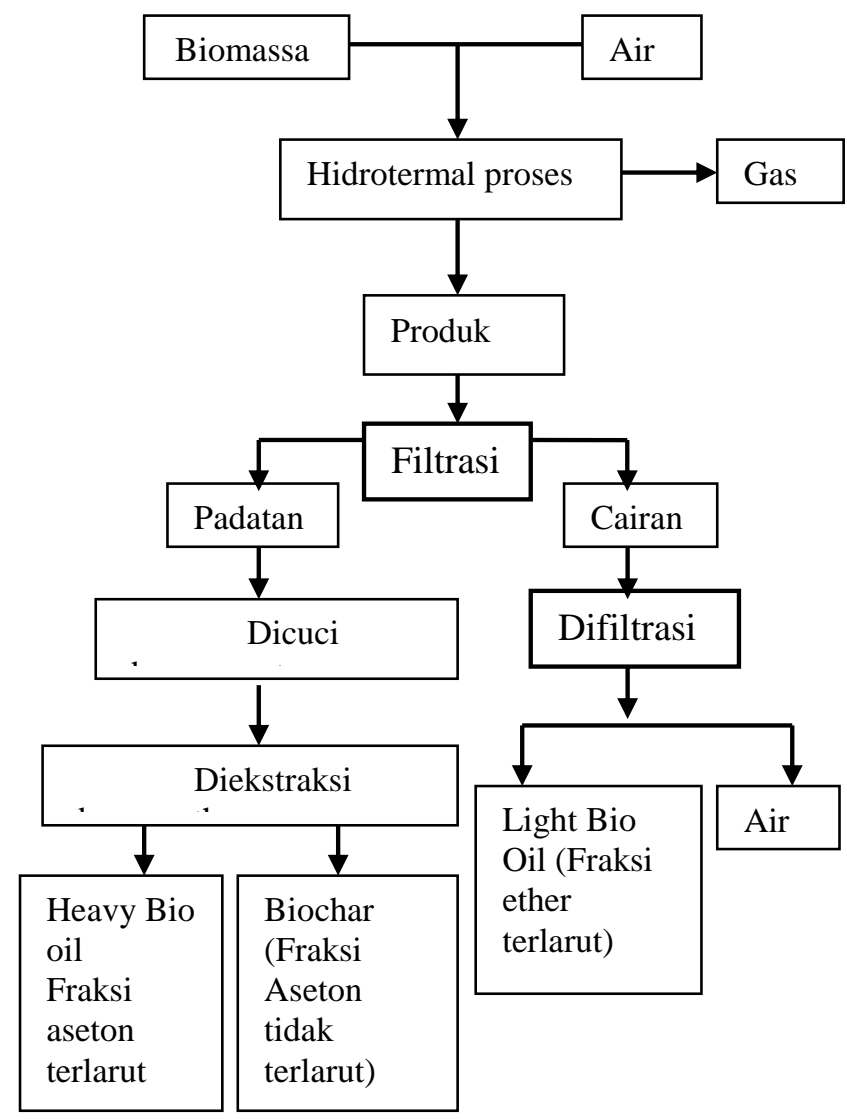

Gambar 2. Tahapan Proses Pembuatan Biochar dengan Metode Hidrotermal Sumber: (Tekin, 2014)

Setelah terbentuk biochar maka memerlukan proses untuk menghasilkan karbon aktif yaitu dengan proses aktivasi terhadap biochar yang terbentuk melalui aktivasi. Aktivasi dilakukan secara fisik, kimia maupun fisik kimia dengan tahapan sebagaimana gambar 3 . 


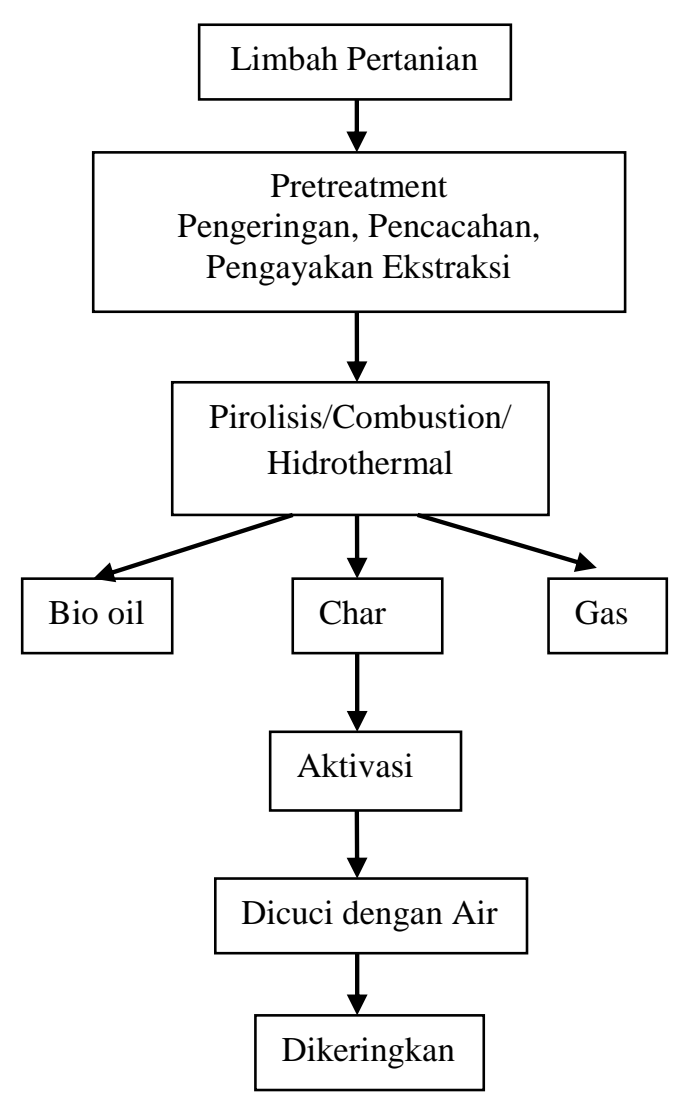

Gambar 3. Tahapan Proses Pembuatan Karbon aktif

Sumber: (Dermibas, 2009)

Karbon aktif yang dihasilkan dari biomassa tanaman umumnya lebih rendah kualitasnya dibandingkan dengan antrasit, batubara dan gambut (Yahya, 2015) karena terdapat material volatil (Lua, 2006) yang tertinggal pada GAC yang terbentuk. Sehingga diperlukan upaya untuk meningkatkan kualitas dengan proses aktivasi. Tujuannya adalah untuk meningkatkan kualitas karbon yang dihasilkan menjadi karbon aktif yang mempunyai micropori, mesopori, makropori yang kecil namun luas permukaan besar (Nasri, N.S., 2014; Largitte, L., 2015). Sehingga setelah proses karbonisasi dilanjutkan dengan proses aktivasi. Proses aktivasi dapat dilakukan dengan aktivasi fisik, kimia serta gabungan fisik-kimia maupun kimia-fisik (Hesas, R.H., 2015; Widyastuti, A., 2013) dengan berbagai jenis aktivator dan metoda.

\section{Aktivasi Karbon Aktif Secara Fisik}

Proses aktivasi fisik dilakukan menggunakan steam (Cagnon, 2009., Hidayu, 2013, Amosa, 2015), pemanasan (Foo, 2012, Meisrilestari, 2013., Nasri, 2014) dan dengan gas $\mathrm{CO}_{2}$ (Niva, 2011., Omri, 2013., Hashemian, 2013).

Perbedaan mendasar aktivasi fisik dan kimia adalah tahapan proses dan suhu aktivasi. Aktivasi fisik dilakukan pada suhu yang lebih tinggi (800$1000{ }^{\circ} \mathrm{C}$ ) sedangkan aktivasi kimia pada suhu lebih rendah $\left(200-800{ }^{\circ} \mathrm{C}\right)$.

\section{Aktivasi Karbon Aktif Secara Kimia}

Selain aktivasi secara fisik dilakukan juga aktivasi kimia menggunakan $\mathrm{ZnCl}_{2}$ (Hesas, 2013., Ceyhan, 2013., Meisrilestari, 2013, Niva, 2011), $\mathrm{H}_{2} \mathrm{SO}_{4}$ (Lee, 2014), $\mathrm{P}_{3} \mathrm{PO}_{4}$ (Widyastuti, 2013., Niva, 2011) dan KOH (Hesas, 2015). Aktivasi dengan secara kimia menghasilkan karbon aktif yang lebih baik dibanding aktivasi secara fisik. Zat lain yang digunakan adalah ammonium salts, borates, calcium dioxide, komponen ferri dan ferro, mangan dioksida, garam nikel, asam hidroklorik, asam nitrit dan asam sulfat (Mohan, D., 2006). Pada aktivasi secara kimia terjadinya penggabungan kontak antara inorganic additive, logam klorida termasuk aink klorida atau asam phosphoric kedalam biochar sebelum dikarbonisasi tahap dua. (Mohan, 2006). Karbon aktif dengan struktur dinding meso dan mikropori dihasilkan dari penggunaan $\mathrm{ZnCl}$. Sedangkan aktivasi $\mathrm{KOH}$ akan meningkatkan luas permukaan karbon aktf volume porinya (Mohan, 2006). Bahan kimia yang digunakan sebagai activator adalah bahan kimia yang bersifat basa seperti $\mathrm{KOH}, \mathrm{K}_{2} \mathrm{CO}_{3}, \mathrm{NaOH}$, dan $\mathrm{Na}_{2} \mathrm{CO}_{3}$, bersifat alkali tanah dengan garam metal $\mathrm{AlCl}_{3}$, $\mathrm{FeCl}_{3}$, and $\mathrm{ZnCl}_{2}$ atau menggunakan bahan kimia bersifat asam $\mathrm{H}_{3} \mathrm{PO}_{4}, \mathrm{H}_{2} \mathrm{SO}_{4}$. Bahan tersebut akan mendekomposisi material ofkarbon, menghalangi terbentunya tar dan meningkatkan karbon yield (Kumar, 2015). Untuk mendapatkan karakteristik karbon aktif yang baik maka dapat dilakukan peningkatan rasio carbon dengan activator, suhu dan waktu aktivasi. 
Penelitian yang ada lebih banyak $\left(\mathrm{V}_{\text {mic }}\right)$, Mikropori surface area $\left(\mathrm{S}_{\text {mic }}\right)$. Namun membandingkan bahan activator terhadap karakteriktik kimia permukaan karbon aktif yang kualitas karbon aktif yang terbentuk meliputi dihasilkan yang diakibatkan penggunaan activator Surface area $\left(\mathrm{S}_{\mathrm{BET}}\right)$, Total volume dan rata rata kimia belum dilakukan ukuran pori ( $\mathrm{V}_{\text {tot }}$ dan $\left.\mathrm{DAC}\right)$, Mikropori volume

Tabel 4. Berbagai metode aktivasi karbon aktif

\begin{tabular}{|c|c|c|c|}
\hline $\begin{array}{l}\text { Jenis } \\
\text { Aktivasi }\end{array}$ & Aktivator & Metode Aplikasi & Referensi \\
\hline \multirow[t]{10}{*}{ Fisik } & \multirow[t]{3}{*}{ Steam } & Suhu $800^{\circ} \mathrm{C}$ selama $120 \mathrm{~min}$ & Cagnon, 2009 \\
\hline & & $\begin{array}{l}\text { Suhu } 765^{\circ} \mathrm{C} \text { selama } 77 \mathrm{~min} \text {, debit } \\
129 \mathrm{ml} / \mathrm{jam}\end{array}$ & Hidayu, 2013 \\
\hline & & $\begin{array}{l}\text { Suhu } 900{ }^{\circ} \mathrm{C} \text { dengan debit steam } 2,4,6,8 \text {, } \\
10 \mathrm{~mL} / \mathrm{min} \text { selama } 15 \mathrm{~min} .\end{array}$ & Amosa, 2015 \\
\hline & \multirow[t]{5}{*}{ Pemanasan } & Dalam furnace $750^{\circ} \mathrm{C}$ selama 3 jam & $\begin{array}{l}\text { Meisrilestari, } \\
2013\end{array}$ \\
\hline & & Dalam furnace $800^{\circ} \mathrm{C}$ selama 2 jam & Nasri, 2014 \\
\hline & & $\begin{array}{l}\text { Dengan pemanasan microwave } 2,45 \mathrm{GHz} \text {, } \\
\text { power } 90,180,360,600,800 \text { watt }\end{array}$ & Foo, 2012 \\
\hline & & $\begin{array}{l}\text { Dengan pemanasan microwave power } 600 \\
\text { watt selama 10menit }\end{array}$ & Foo, 2012 \\
\hline & & $\begin{array}{l}\text { Dengan pemanasan microwave power } 550 \text { - } \\
850 \text { watt selama } 5-45 \text { menit }\end{array}$ & \\
\hline & \multirow[t]{2}{*}{ Gas CO2 } & & $\begin{array}{l}\text { Hashemian, } 2013 \\
\text { Omri, } 2013\end{array}$ \\
\hline & & $\begin{array}{l}\text { Pemanasan suhu } 850^{\circ} \mathrm{C} \text { dengan debit } \mathrm{CO}_{2} \\
100 \mathrm{~mL} / \mathrm{min} \text { selama } 1-7 \mathrm{jam} \text { dengan } \\
\text { kecepatan pemanasan } 10^{\circ} \mathrm{C} / \mathrm{min}\end{array}$ & Niya, 2011 \\
\hline
\end{tabular}




\begin{tabular}{|c|c|c|c|}
\hline $\begin{array}{l}\text { Jenis } \\
\text { Aktivasi }\end{array}$ & Aktivator & Metode Aplikasi & Referensi \\
\hline \multirow[t]{10}{*}{ Kimia } & \multirow[t]{6}{*}{$\mathrm{ZnCl}_{2}$} & $\begin{array}{l}0.15,0.28,0.40,0.53,0.65,0.780 .90 \\
\text { berat/gram adsorben }\end{array}$ & Hesas, 2013 \\
\hline & & $\begin{array}{l}\text { Tahap } 1 \\
15 \mathrm{ml} \mathrm{ZnCl}_{2} \text { dengan rasio } 1: 1 ; 1: 2 ; 1: 3 ; 1: 4 \\
\text { Mixing pada suhu } 30,50,80^{\circ} \mathrm{C} \text { selama } 3 \text { jam } \\
\text { Tahap } 2 \\
\text { Pemanasan suhu } 150-350^{\circ} \mathrm{C} \text { heating rate } \\
5^{\circ} \mathrm{C} / \mathrm{min}\end{array}$ & Ceyhan, 2013 \\
\hline & & $\begin{array}{l}0.56,1.13,1.69,2.25,2.81 \mathrm{XZn} \text {, berat zinc } \\
\text { mass/gr bahan dipanaskan dan stirer selama } 2 \text { jam } \\
\text { pada suhu } 85^{\circ} \mathrm{C} \text {, } \\
\text { Dilanjutkan dengan microwave oven dengan } \\
\text { daya microwave of } 750,900,1050,1200 \text { dan } \\
1300 \mathrm{~W} \text { dan waktu aktivasi } 5,10,15,20,25 \\
\text { menit }\end{array}$ & Hesas, 2013 \\
\hline & & $\begin{array}{l}250 \mathrm{ml} \mathrm{ZnCl}_{2} 0,1 \mathrm{~N} \text { diamkn } 24 \text { jam cuci dengan } \\
\text { aquades keringkan suhu } 100^{\circ} \mathrm{C} \text { selama } 1 \text { jam }\end{array}$ & $\begin{array}{l}\text { Meisrilestari, } \\
2013\end{array}$ \\
\hline & & $\begin{array}{l}\text { Aktivasi suhu } 500^{\circ} \mathrm{C} \text { selama } 2 \text { jam dengan } \\
\text { kecepatan pemanasan } 5{ }^{\circ} \mathrm{C} / \mathrm{min} \text { dengan debit } \mathrm{N}_{2} \\
100 \mathrm{~mL} / \mathrm{min}\end{array}$ & Niya, 2011 \\
\hline & & $\begin{array}{l}\text { Dipanaskan di suhu } 300-800^{\circ} \mathrm{C} \text { dengan heating } \\
\text { rate } 10{ }^{\circ} \mathrm{C} / \mathrm{min} \text { selama } 1 \text { jam GAC yang } \\
\text { dihasilkan dicuci dengan } 3 \mathrm{M} \mathrm{HCl} \text { dan dipanaskan } \\
\text { pada } 90^{\circ} \mathrm{C} \text { selama } 30 \mathrm{~min} \text {, filter dan dicuci dengan } \\
\text { air hangat sampai pH netral kemudian } \\
\text { dikeringkan pada } 105^{\circ} \mathrm{C} \text { selama } 12 \text { jam. }\end{array}$ & $\begin{array}{l}\text { (Açıkyıldız et al. } \\
\text { 2014) }\end{array}$ \\
\hline & $\mathrm{H}_{2} \mathrm{SO}_{4}$ & $\begin{array}{l}\text { Tandan kosong: } \mathrm{H}_{2} \mathrm{SO}_{4}=4: 3 \text { dengan combustion } \\
250^{\circ} \mathrm{C} \text { selama } 2 \mathrm{jam} \text {, dicuci sampai } \mathrm{pH} 5 \\
\text { dikeringkan } 24 \mathrm{jam} \text { dengan suhu } 110^{\circ} \mathrm{C}\end{array}$ & Lee, 2014 \\
\hline & \multirow[t]{2}{*}{$\mathrm{H}_{3} \mathrm{PO}_{4}$} & $\begin{array}{l}\text { Aktivasi larutan } 10 \% \text { selama } 24 \text { jam kemudian } \\
\text { dioven } 110^{\circ} \mathrm{C} \text { selama } 2 \text { jam }\end{array}$ & $\begin{array}{l}\text { Widyastuti, } \\
2013\end{array}$ \\
\hline & & $\begin{array}{l}\text { Aktivasi suhu } 4500^{\circ} \mathrm{C} \text { selama } 2 \text { jam dengan } \\
\text { kecepatan pemanasan } 5{ }^{\circ} \mathrm{C} / \mathrm{min} \text { dengan debit } \mathrm{N}_{2} \\
100 \mathrm{~mL} / \mathrm{min}\end{array}$ & Niya, 2011 \\
\hline & $\mathrm{KOH}$ & $\begin{array}{l}\text { Rasio } 0,5 ; 1,5 ; 2,5 ; 3,5 \text { Xk (mass } \mathrm{KOH} / \mathrm{gr} \\
\text { adsorben) stirer selama 2jam pd suhu } 85^{\circ} \mathrm{C} \\
\text { dipanaskan sampai titik didih, disimpn di oven } \\
\text { 24jam suhu } 110^{\circ} \mathrm{C}\end{array}$ & Hesas, 2015 \\
\hline
\end{tabular}




\section{DAFTAR PUSTAKA}

Abdolali, A., Guo, W.S., Ngo, H.H., Chen, S.S., Ngyuen, N.C., Tung, K.L., Typical Lignocellulosic wastes And By Products For Biosorption Process In water And Wastewater Treatment, Biosource technology, 2014, 160, 57-66

Ahmaruzzaman, Md., Adsorption of Phenolic Compound On Low Cost Adsorbent : A Review, Advances In Colloid And Interface Science, 2008, 143, 48-67

Bilal, M., Shah., J.A., Ashfaq, T., Gardazi, S.M.H., Tahir, A.A., Pervez, A., Haroon, H., Mahmood, Q., Waste Biomass Adsorbents For Copper Removal From Industrial Wastewater-A Review, Journal of hazardous Materials, 2013, 263, 322333

Crini, G., Non Convebtional Low Cost Adsorbents For Dye Removal : A Review, Bioresource Technology, 2006, 97, 10611085

Foo, K.Y., Hameed, B.H., Microwave-Assisted Preparation And Adsorption Performance of Activated Carbon From Biodiesel Industry Solid Reside : Influence of Operation Parameters, Bioresource Technology, 2012, 103, 398-404

Foo, K.Y., Hameed, B.H., Dynamic Adsorption Behavior of Methylene Blue Onto Oil Palm Shell Granular Activated Carbon Prepared By Microwave Heating, Chemichal Engineering Journal, 2012, 203, 81-87

Foo, K.Y., Hameed, B.H., Preparation Characyerization And Evaluation of Adsorptive Properties of Orange Peel Based Activated Carbon Via Microwave Induced $\mathrm{K}_{2} \mathrm{CO}_{3}$ Activation, Bioresource Technology, 2012, 104, 669-686

Hansen, S.B., Padfields, R., Sgayuti, K., Evers, S., Zakariyah, Z., Mastura, S., Trends In
Global Palm Oil Sustainability Research, Journal of Cleaner Production, 2015, 100, 140-149

Hesas, R.H., Niya, A.A., Daud, W.M.A.W., Sahu, J.N., Microwave-Assisted Production of Activated Carbons From Oil Palm Shell In Presence of $\mathrm{CO}_{2}$ or $\mathrm{N}_{2}$ For $\mathrm{CO} 2$ Adsorption, Jornal of Industrial And Engineering Chemistry, 2015, 24, 196-205

Hidayu, A.R., Mohammad, N.F., Matali, S., Sharifah, A.S.A.K., Characterization of Activated Carbon Prepared From Oil Palm Empty Fruit Bunch Using BET and FT-IR Techniques, Procedia Engineering, 2013, 68, 379-384

Kong, S.H., Loh, S.K., Bachman. R.T., Rahim, S.A., Salimon, J., Bichar From Oil Palm Biomass : A Review of Its Potential And Challenges, Renewable and Sustainable Energy, 2014, 39, 729-739

Hossain, M.A., Ngo, H.H., Guo, W.S., Nguyen T.V., Short Communication Palm Oil Fruit Shells As Biosorbent For Copper Removal From Water and Wastewater : Experiments and Sorption Models, Bioresource Technology, 2012, 113, 97-101

Kumar, A., Jena, H.M., High surface area microporous activated carbons prepared from Foxnut (Euryale ferox) shell by zinc chloride activationArvind, Jurnal Applied Surface Science, 2015, 356, 753-761

Largitte, L., Brudey, T., Tant, T., Dumesnil, P.C., Lodewyckx, P., Review Comparison of The Adsorption of Lead By Activated Carbons From Three Lignocellulosic Precursors, Microporous and Mesoporous Materials, 2015, 1-11

Lee, T., Zubir, Z.A., Jamil, F.M., Matsumoto, A., Combustion and Pyrolysis of Activated Carbon Fibre From Oil Palm Empty Fruit Bunch Fibre Assisted Through Chemical Activation With Acid Treatment, Journal 
of Analytical and Applied Pyrolisis, 2014, $110,408-418$

Meisrilestari, Y., Khomaini, R., Wijayanti, H., Pembuatan Arang Aktif Dari Cangkang Kelapa Sawit Dengan Aktivasi Secara Fisik, Kimia dan Fisika Kimia, Jurnal Konversi, 2013, 2(1), 46-51

Mohan, D., Sarswat, A., Ok, Y.S., Pittman Jr. C.U., Organic And Inorganic Contaminants Removal From waste With Biochar A Renewable Low Cost And Sustainable Adsorbent-A Critical Review, Bioresource Technology, 2014, 160, 191202

Mohan, D., Pttman Jr, C.U., Review Activated Carbons and Low Cost Adsorbents For Remediation of Tri and Hexavalent Chromium From Water, Journal of Hazardous Material, 2006, B.137, 762-811

Nasri, N.S., Hamza, U.D., Ismail, S.N., Ahmed, M.M., Mohsin, R., Assessment of Porous Carbons Derived From Sustainable palm Solid Waste For Carbon Dioxide Capture, Journal of Cleaner Production, 2014, 71, 148-157

Oramahi, H.A., Wahida, Diba, F., Nurhaida, Yoshimura, T., Optimization of Production of Lignocellulosic Biomass Bio-Oil From oil Palm Trunk, Procedia Environmental Sciences, 2015, 28, 769-777

Saka, C., BET, TG-DTG, FT-IR, SEM, Iodine Number Analysis and Preparation of Activated Carbon From Acorn Shell by Chemical Activation With $\mathrm{ZnCl}_{2}$, Jornal of Analytical and Applied Pyrolysis, 2012, 95, 21-24
Sharma, P., Kaur, K., Sharma, M., Sahore, V., A Review On Applicability of Naturally Available Adsorbents For The Removal of Hazardous Dyes From Aqueous Waste, Environmental Monitoring Assessment, 2011, 183, 151-195

Sivashankar, R., Sathya, A.B., Vasantharaj, K., Sivasubramanian, V., Magnetic Composite An Environmental Super Adsorbent For Dye Sequestration-A Review, Environmental nanotechnology, Monitoring \& Management, 2014, 1-2, 3649

Sun, Ke., Kang, M., Ro, K.S., Libra, J.A., Zhao, Y., Xing, B., Variation In Sorption Of Propiconazole With Biochar: The Effect of Temperature, Mineral, Molecular Structure an Nano-Porosity, Chemosphere, 2015

Saswattecha K., Kroeze, C., Jwjit, W., Hein, L., Assessing The Environmental Impact Of Palm Oil Produced In Thailand, Journal of Cleaner Production, 2015, 100, 150-169

Tan, I.A.W., Ahmad, A.L, Hameed, B.H., Adsorption Isotherm, Kinetics, Thermodynamics and Desorption Studies of 2,4,6-Trichlorophenol on Oil Palm Empty Fruit Bunch Based Activated Carbon, 2009, 164, 473-482

Widyastuti, A., Sitorus, B., Jayuska, A., Karbon Aktif Dari Limbah Cangkang Sawit Sebagai Adsorben Gas Dalam Biogas Fermentasi Anaerobik Sampah Organik, Jurnal JKK, 2013, 2(1), 30-33

Yahya, M.A., Al-Qodah, Z., Ngah, C.W.Z., Agricultural Bio-Waste Material As Potential Sustainable Precursors Used For Activated Carbon Production : A Review, 2015, 56, 218-235 